\title{
TOXICITY OF UREA AND ITS ROLE IN THE PATHOGENESIS OF UREMIA *
}

\author{
By EVELYN FRANCES GROLLMAN AND ARTHUR GROLLMAN
}

(From the Department of Experimental Medicine, University of Texas Southwestern Medical School, Dallas, Texas)

(Submitted for publication October 17, 1958; accepted January 5, 1959)

It is generally assumed that urea is nontoxic and that even the high concentrations present in uremia are innocuous and do not contribute to the symptoms encountered in this condition. In support of this assumption is the fact that the blood in the elasmobranch fishes contains 330 to 440 $\mathrm{mM}$ (about 2 per cent) of urea per L. The original purpose of the present study was to utilize this assumed inertness of urea in order to determine the effect of the presence of one molecular species in high concentration on the electrolyte and water composition of the body. However, it soon became apparent that urea in high concentrations, contrary to the generally accepted notion, was lethal and that many of the abnormalities noted in uremia could be elicited by this substance.

\section{METHODS}

General procedure. Intermittent peritoneal lavage, as described elsewhere (1), was utilized to maintain the desired level of urea in the extracellular fluid of the nephrectomized dog. The kidneys were removed under ether anesthesia through the dorsolumbar approach with an interval of 7 to 14 days between the two operations. Sterile solutions available commercially (Peridial@) ${ }^{1}$ or prepared as described previously (1) were utilized for the peritoneal exchanges. One $\mathrm{L}$. of the solution, the electrolyte and water composition of which approximated normal extracellular fluid, was injected intraperitoneally and exchanged, twice daily (2). Varying amounts of urea ( 5 to $30 \mathrm{Gm}$. per L.) were added to these solutions in order to maintain the concentration at the desired level. The animals were killed by exsanguination after 4 to 10 days, at a time when they manifested severe symptoms of uremia.

Analytical procedures. The tissues were placed in dry, glass-stoppered weighing bottles and dried in vacuo at $40^{\circ}$ C. to constant weight. They were then defatted with petroleum ether, dried again, reweighed and extracted

* This work was supported in part by the Dixie and Grady Vaughn Fund.

${ }^{1}$ Kindly supplied through the courtesy of Dr. E. B. McLean, Research Director, The Cutter Laboratories, Berkeley, Cal. with a known volume of $0.75 \mathrm{~N} \mathrm{HNO}_{3}$. Urea was determined, after neutralization of the tissue extract, by the urease procedure of Van Slyke and Cullen (3); chloride, as described by Laramore and Grollman (4); and sodium and potassium by a Beckman flame photometer.

The urea used in the present study was a chemically pure preparation (Merck Reagent Crystals). The injection intraperitoneally of a liter of a 5 per cent solution of this preparation induced no pyrogenic or other obvious toxic reaction such as has been reported to follow the injection intravenously of commercially available preparations of urea in the human. Intact dogs treated with large amounts of urea for as long as a month revealed no symptoms of toxicity, but the rapid excretion of the urea precluded their use for the purpose of the present study.

\section{RESULTS}

\section{General symptoms}

The period of survival of the six dogs used in the present study and other pertinent data are summarized in Table I. As noted in Column 2, the animals were maintained for periods of four to nine days. One animal died after four days; another after seven days; the others were killed five to nine days after initiating the peritoneal dialysis, at which time they were drowsy or comatose and the urea content of their blood serum had attained the values shown in Column 4 of the table.

Symptoms of intoxication were apparent clinically two to four days after beginning the dialysis, at which time the blood urea content was 370 to $480 \mathrm{mg}$. per cent. The first symptoms noted were weakness and anorexia, the animals refusing their food, manifesting no interest in their surroundings and lying inert, in contrast to the normal behavior of animals maintained with only moderately elevated blood urea levels (2). Vomiting and retching soon followed and persisted, with diarrhea terminating in hemorrhage from the bowel. The body temperature remained normal for three or four days but then gradually declined to 90 to 
TABLE I

Effects of an elevated urea content of the blood in the nephrectomized dog

\begin{tabular}{|c|c|c|c|c|c|}
\hline Dog & $\begin{array}{c}\text { Duration } \\
\text { of } \\
\text { experiment }\end{array}$ & $\begin{array}{l}\text { Time of } \\
\text { onset of } \\
\text { symptoms }\end{array}$ & $\begin{array}{l}\text { Urea content } \\
\text { of blood at } \\
\text { onset of } \\
\text { symptoms }\end{array}$ & $\begin{array}{l}\text { Urea content } \\
\text { of blood at } \\
\text { termination } \\
\text { of experiment }\end{array}$ & $\begin{array}{c}\text { Condition } \\
\text { of dog at } \\
\text { termination } \\
\text { of experiment }\end{array}$ \\
\hline no. & days & days & $m g . \%$ & $G m . / L$ & \\
\hline 1 & 8 & 4 & 430 & 16.9 & Comatose \\
\hline 2 & 4 & 2 & 480 & 14.4 & Dead \\
\hline 3 & 6 & 3 & 370 & 15.9 & Drowsy \\
\hline 4 & 9 & $2 \frac{1}{2}$ & 380 & 9.0 & Drowsy \\
\hline 5 & 7 & $2 \frac{1}{4}$ & 410 & 8.6 & Dead \\
\hline 6 & 5 & 3 & 450 & 5.4 & Drowsy \\
\hline
\end{tabular}

TABLE II

The effect of a high urea level of the blood on the water and electrolyte content of the tissues of Dog No. 1 (cf. Table I)

\begin{tabular}{|c|c|c|c|c|c|}
\hline Tissue & Urea & Water & Sodium & Potassium & Chloride \\
\hline $\begin{array}{l}\text { Blood serum } \\
\text { Heart } \\
\text { Liver } \\
\text { Skeletal muscle } \\
\text { Spleen } \\
\text { Stomach }\end{array}$ & $\begin{array}{c}\mathrm{Gm} . / \mathrm{Kg} . \mathrm{H}_{2} \mathrm{O} \\
16.9 \\
16.7 \\
17.7 \\
17.0 \\
18.0 \\
17.0\end{array}$ & $\begin{array}{c}\text { Gm./Kg. } \\
912 \\
757 \\
727 \\
742 \\
748 \\
755\end{array}$ & $\begin{array}{c}m E q . / K g . \\
136 \\
48 \\
37 \\
64 \\
65 \\
56\end{array}$ & $\begin{array}{c}m E q . / K g . \\
5.2 \\
99 \\
102 \\
83 \\
94 \\
76\end{array}$ & $\begin{array}{c}m E q . / K g \\
94 \\
35 \\
25 \\
23 \\
35 \\
49\end{array}$ \\
\hline
\end{tabular}

$95^{\circ} \mathrm{F}$. (rectally) when the experiment was terminated. Symptoms gradually increased in intensity and culminated finally with the animals in a state of deep torpor or coma.

\section{Biochemical changes}

The urea, water and electrolyte content of the tissues at the termination of the experiments are shown in Tables II through VII. All values are

TABLE III

The effect of a high urea level of the blood on the water and electrolyte content of the tissues of Dog No. 2 (cf. Table I)

\begin{tabular}{|c|c|c|c|c|c|}
\hline Tissue & Urea & Water & Sodium & Potassium & Chloride \\
\hline $\begin{array}{l}\text { Blood serum } \\
\text { Heart } \\
\text { Liver } \\
\text { Skeletal muscle } \\
\text { Spleen }\end{array}$ & $\begin{array}{c}\mathrm{Gm} . / \mathrm{Kg} . \mathrm{H}_{2} \mathrm{O} \\
14.4 \\
14.3 \\
14.4 \\
14.5 \\
14.9\end{array}$ & $\begin{array}{c}G m . / K g . \\
915 \\
766 \\
736 \\
748 \\
750\end{array}$ & $\begin{array}{c}m E q . / K g . \\
140 \\
49 \\
41 \\
67 \\
68\end{array}$ & $\begin{array}{c}m E q . / K g . \\
4.6 \\
80 \\
90 \\
92 \\
96\end{array}$ & $\begin{array}{c}m E q . / K g . \\
101 \\
28 \\
30 \\
26 \\
40\end{array}$ \\
\hline
\end{tabular}

TABLE IV

The effect of a high urea level of the blood on the water and electrolyte content of the tissues of Dog No. 3 (cf. Table I)

\begin{tabular}{|c|c|c|c|c|c|}
\hline Tissue & Urea & Water & Sodium & Potassium & Chloride \\
\hline $\begin{array}{l}\text { Blood serum } \\
\text { Heart } \\
\text { Liver } \\
\text { Skeletal muscle } \\
\text { Spleen } \\
\text { Stomach }\end{array}$ & $\begin{array}{c}\mathrm{Gm} . / \mathrm{Kg} . \mathrm{H}_{2} \mathrm{O} \\
15.9 \\
15.9 \\
16.8 \\
16.4 \\
16.6 \\
16.0\end{array}$ & $\begin{array}{c}\text { Gm./Kg. } \\
910 \\
760 \\
730 \\
750 \\
754 \\
760\end{array}$ & $\begin{array}{c}m E q . / K g . \\
140 \\
50 \\
41 \\
69 \\
71 \\
58\end{array}$ & $\begin{array}{c}m E q . / K g . \\
5.1 \\
98 \\
94 \\
86 \\
90 \\
70\end{array}$ & $\begin{array}{c}m E q . / K g . \\
101 \\
36 \\
28 \\
26 \\
32 \\
51\end{array}$ \\
\hline
\end{tabular}


TABLE V

The effect of a high urea level of the blood on the water and electrolyte content of the tissues of Dog No. 4 (cf. Table I)

\begin{tabular}{|c|c|c|c|c|c|}
\hline Tissue & Urea & Water & Sodium & Potassium & Chloride \\
\hline $\begin{array}{l}\text { Blood serum } \\
\text { Heart } \\
\text { Liver } \\
\text { Skeletal muscle } \\
\text { Spleen } \\
\text { Stomach }\end{array}$ & $\begin{array}{c}\mathrm{Gm} . / \mathrm{Kg} . \mathrm{H}_{2} \mathrm{O} \\
9.0 \\
9.0 \\
9.0 \\
9.6 \\
9.9 \\
9.2\end{array}$ & $\begin{array}{c}G m . / K g . \\
905 \\
780 \\
786 \\
764 \\
753 \\
758\end{array}$ & $\begin{array}{c}m E q . / K g . \\
130 \\
38 \\
36 \\
23 \\
44 \\
37\end{array}$ & $\begin{array}{c}m E q . / K g . \\
5.0 \\
81 \\
98 \\
96 \\
90 \\
74\end{array}$ & $\begin{array}{c}m E q . / K g . \\
93 \\
27 \\
31 \\
24 \\
33 \\
44\end{array}$ \\
\hline
\end{tabular}

expressed in terms of fat-free wet tissue except for urea and water which are expressed in terms of the water content and fresh wet-weight of the tissues, respectively. As noted in the second column of the tables, the urea, as anticipated, diffuses throughout the body water and is present in the tissue water in a concentration equal to, and in some instances slightly greater than, that present in the extracellular water. The differences noted, however, with the exception of the spleen, are slight.

That the effects reported in Tables II through VII are not secondary to electrolyte or acid-base disturbances induced by intermittent peritoneal lavage is shown in Table VIII in which the urea, sodium, potassium, chloride and bicarbonate contents of the blood are given after equilibration with urea had occurred. As demonstrated previously $(1,2)$ the exchange of solutes across the peritoneal membrane conforms to the physicochemical laws of distribution across a semipermeable membrane. The composition of the lavage fluid is such as to maintain a relatively normal electrolyte and acidbase balance in the extracellular fluid in the absence of the kidneys.

In Table IX are reproduced data on tissue analyses on dogs maintained by intermittent peritoneal lavage following bilateral nephrectomy as compared to normal control animals. The observed deviations, which are minor as compared to

TABLE VI

The effect of a high urea level of the blood on the water and electrolyte content of the tissues of Dog No. 5 (cf. Table I)

\begin{tabular}{|c|c|c|c|c|c|}
\hline Tissue & Urea & Water & Sodium & Potassium & Chloride \\
\hline $\begin{array}{l}\text { Blood serum } \\
\text { Heart } \\
\text { Liver } \\
\text { Skeletal muscle } \\
\text { Spleen } \\
\text { Stomach }\end{array}$ & $\begin{array}{c}\mathrm{Gm} . / \mathrm{Kg} . \mathrm{H}_{2} \mathrm{O} \\
8.6 \\
8.6 \\
8.8 \\
9.0 \\
9.3 \\
8.8\end{array}$ & $\begin{array}{c}\text { Gm./Kg. } \\
910 \\
790 \\
795 \\
770 \\
761 \\
768\end{array}$ & $\begin{array}{c}m E q . / K g . \\
138 \\
46 \\
39 \\
24 \\
36 \\
35\end{array}$ & $\begin{array}{c}m E q . / K g . \\
5.1 \\
83 \\
95 \\
99 \\
92 \\
70\end{array}$ & $\begin{array}{c}m E q . / K g . \\
101 \\
25 \\
33 \\
26 \\
35 \\
40\end{array}$ \\
\hline
\end{tabular}

TABLE VII

The effect of a high urea level of the blood on the water and electrolyte content of the tissues of Dog No. 6 (cf. Table I)

\begin{tabular}{|c|c|c|c|c|c|}
\hline Tissue & Urea & Water & Sodium & Potassium & Chloride \\
\hline $\begin{array}{l}\text { Blood serum } \\
\text { Heart } \\
\text { Liver } \\
\text { Skeletal muscle } \\
\text { Spleen } \\
\text { Stomach }\end{array}$ & $\begin{array}{c}\mathrm{Gm} . / \mathrm{Kg} . \mathrm{H}_{2} \mathrm{O} \\
5.4 \\
5.4 \\
5.5 \\
5.6 \\
5.7 \\
5.5\end{array}$ & $\begin{array}{c}\text { Gm./Kg. } \\
908 \\
775 \\
790 \\
760 \\
770 \\
762\end{array}$ & $\begin{array}{c}m E q . / K g . \\
140 \\
42 \\
41 \\
30 \\
39 \\
34\end{array}$ & $\begin{array}{c}m E q . / K g . \\
4.9 \\
86 \\
88 \\
101 \\
98 \\
81\end{array}$ & $\begin{array}{c}m E q . / K g . \\
99 \\
24 \\
34 \\
29 \\
30 \\
48\end{array}$ \\
\hline
\end{tabular}


TABLE VIII

The electrolyte content of the blood plasma of bilaterally nephrectomized dogs subjected to intermittent peritoneal lavage with solutions containing various urea concentrations

\begin{tabular}{|c|c|c|c|c|c|c|}
\hline Dog & $\begin{array}{c}\text { Days after } \\
\text { nephrectomy }\end{array}$ & Urea & Sodium & Potassium & Chloride & Bicarbonate \\
\hline $\begin{array}{c}\text { no. } \\
1 \\
2 \\
3 \\
4 \\
5 \\
6\end{array}$ & $\begin{array}{l}\mathbf{5} \\
4 \\
\mathbf{5} \\
7 \\
6 \\
\mathbf{5}\end{array}$ & $\begin{array}{r}G m . / L \\
14.9 \\
14.4 \\
15.6 \\
8.6 \\
8.0 \\
5.4\end{array}$ & $\begin{array}{c}m E q . / L . \\
142 \\
140 \\
145 \\
143 \\
141 \\
140\end{array}$ & $\begin{array}{c}m E q . / L \\
4.6 \\
4.6 \\
4.3 \\
4.4 \\
4.2 \\
4.9\end{array}$ & $\begin{array}{c}m E q . / L \\
100 \\
101 \\
98 \\
103 \\
105 \\
99\end{array}$ & $\begin{array}{c}m E q . / L . \\
20.0 \\
21.2 \\
22.0 \\
20.1 \\
18.9 \\
23.4\end{array}$ \\
\hline
\end{tabular}

those obtained in the present study, may be attributed to the increased extracellular fluid volume and the hypertension induced by nephrectomy.

Urea is present in blood and other aqueous solutions as a dimer (5) but is apparently not bound by the blood proteins to any appreciable extent. When added in a concentration of 3 per cent to blood serum it was found to be completely filtrable through a cellophane membrane. The unequal distribution of urea between the plasma and red blood cell as found by Ralls and Crohn (6) and between the intracellular and extracellular fluid

TABLE IX

Water and electrolyte contents of the tissues of nephrectomized dogs maintained by intermittent peritoneal lavage (experimental) as compared to normal (control) animals*

\begin{tabular}{lccc}
\hline \multicolumn{1}{c}{ Tissue } & Water & Sodium & Potassium \\
\hline Brain & Gm./Kg. & $m E q . / K g$. & $m E q . / K g$. \\
Control & $775 \pm 2.8$ & $56.9 \pm 1.75$ & $98.4 \pm 0.90$ \\
Experimental & $778 \pm 16.6$ & $59.3 \pm 1.85$ & $97.5 \pm 6.54$ \\
Heart & & & \\
Control & $772 \pm 22.0$ & $40.1 \pm 2.14$ & $84.8 \pm 2.38$ \\
Experimental & $779 \pm 26.0$ & $42.5 \pm 4.25$ & $84.1 \pm 8.52$ \\
Liver & & & \\
Control & $707 \pm 18.2$ & $36.4 \pm 1.9$ & $89.9 \pm 1.17$ \\
Experimental & $710 \pm 16.2$ & $39.5 \pm 5.2$ & $90.1 \pm 2.15$ \\
Skeletal muscle & & & \\
Control & $762 \pm 2.3$ & $26.7 \pm 1.4$ & $112.2 \pm 1.23$ \\
Experimental & $768 \pm 3.1$ & $29.2 \pm 2.1$ & $110.4 \pm 10.05$ \\
Spleen & & & \\
Control & $777 \pm 2.5$ & $31.6 \pm 0.2$ & $115.5 \pm 1.10$ \\
Experimental & $769 \pm 14.8$ & $33.5 \pm 1.4$ & $112.2 \pm 2.40$ \\
Gut & & & \\
Control & $772 \pm 22.0$ & $43.5 \pm 1.00$ & $103.1 \pm 1.11$ \\
Experimental & $780 \pm 35.4$ & $41.0 \pm 5.65$ & $89.1 \pm 8.46$
\end{tabular}

* The results represent the average values obtained on a series of six animals. in the present studies may be attributed either to binding on some cellular component or to partial dissociation of the urea dimer within the cell (5).

There was, in general, a reduction of the water content of the tissues which was reflected in dehydration of the tissue as noted at autopsy. Although this may be secondary to the increased total osmotic pressure of the tissue fluids due to their high urea content, it more probably reflects the anorexia, vomiting and reduced water intake of the animals.

As noted in the last three columns of Tables V through VII, the electrolyte pattern of the blood and tissues is not materially altered by the presence of $150 \mathrm{mM}$ of urea per L. in the body fluids. However, when the urea content is increased to $280 \mathrm{mM}$, as in Tables II through IV, there is an increase in the sodium and chloride contents with a corresponding decrease in the potassium contents of certain tissues, particularly the skeletal muscle and spleen. These changes reflect the toxic effects of urea superimposed on the effects of nephrectomy which induces similar effects of a lesser degree in animals maintained by intermittent peritoneal lavage as in the present experiments (7).

\section{DISCUSSION}

The procedure used in the present study permits one to dissociate the effect of a high urea level from that induced by the other abnormalities which accompany renal insufficiency with nitrogen retention and give rise to the clinical pattern designated as "uremia." Dogs maintained on intermittent peritoneal lavage, as used in the present study, but without the addition of urea to the dialysis fluid, may be maintained in apparently normal condition for several months except for the 
development of hypertension (2). Since the only variable introduced in the present experiments was a high urea content of the extracellular fluid, the observed abnormalities in the clinical state of the animals must be attributed to the elevated urea.

Although many of the symptoms of "uremia" are undoubtedly attributable to acidosis, electrolyte-water imbalance and other accompaniments of renal insufficiency, some of the toxic manifestations are apparently due to the accumulation of urea, rather than to the creatinine, uric acid or other unknown products of catabolism, as assumed hitherto.

Although the concentrations of urea used in some of the experiments were purposely elevated beyond that normally observed, toxic effects were noted at concentrations encountered clinically and it may be inferred that even lower concentrations might, if maintained for prolonged periods, induce equally noxious effects.

The earliest and most characteristic symptoms of "uremia" are weakness and anorexia. This was also the first symptom observed in the present study and was elicited at blood levels of urea comparable to those seen in severe renal insufficiency in the human. Nausea and vomiting was a constant feature in our dogs as in the human subject.

Although such neurological disturbances as headache or abnormal sensations cannot be detected in the experimental animal, disturbances in the mental state with coma terminally were apparent. Diarrhea was an early symptom, culminating in ulcerative colitis and hemorrhage from the bowel. On the other hand, the convulsions and twitching common in the uremic patient were not observed in the experimental animal and are probably cerebral in origin and secondary to alterations in salt and water metabolism. Itching was likewise not observed in the present experiments and may be attributed to the fact that, unlike the human, sweating does not occur in the dog and hence there is no accumulation of urea on the skin.

Since acidosis, water-electrolyte balance and the accumulation of other catabolites was avoided by the procedure used in the present experiments, one must attribute the observed symptoms to the presence of urea in high concentrations and conclude that, contrary to generally accepted notions, this substance is noxious when presented chroni- cally to the tissues in high concentration as in terminal renal insufficiency.

The observed toxicity of urea is not surprising if one considers the capacity of this agent to react with the vital components of the cell. Its noxious effects may be attributed either to its specific action on the cell or to the hypertonicity induced by its presence in high concentration throughout the body fluids. A direct action of urea on certain components of the cell may result from its demonstrated affinity for proteins with disruption of vital enzyme systems. Thus, urea has been shown to combine with heme (8), plasma albumin (9) and sodium deoxyribonucleate (10) and to induce denaturation (11) or disruption of the molecule (10). Although the concentrations of urea required to demonstrate these effects in vitro are of a much greater magnitude than those used in the present experiments, some reactions would be anticipated to occur at lower concentrations which would account for the present observations.

The failure of previous attempts to demonstrate the toxicity of urea is explained by the fact that the methods used were inadequate for maintaining a high concentration of urea in the tissues for prolonged periods. Because of its ready diffusibility and rapid elimination by the kidney, the injection of even large doses results only in a brief concentration of urea in the tissues. However, in rabbits with ligated ureters the injection of $2 \mathrm{Gm}$. of urea per $\mathrm{Kg}$. of body weight has been reported to induce death within one hour with an accumulation of urea in variable amounts in certain tissues (12). The disruptive effects of urea on the electrolyte content of the tissues demonstrated in the present study may in part account for the similar dislocations observed in acute uremia (13).

\section{SUMMARY}

High concentrations of urea (540 to $1,690 \mathrm{mg}$. per cent) were maintained in the extracellular fluid of nephrectomized dogs by means of intermittent peritoneal lavage. This technique permits the maintenance of the other components of the extracellular fluid constant and thus allows one to study the specific effects of urea. High concentrations of urea induce many of the symptoms encountered in uremia which have been attributed hitherto to changes other than the accumulation of urea. 
Of the various symptoms observed in the late stages of chronic renal failure, it would appear from the present observations that many of these previously attributed to some unknown catabolite accumulating in the uremic patient may be due to the effect of the accumulated urea previously looked upon as an innocuous agent. The presence of high urea levels also induces certain dislocations of the electrolyte composition of the tissues which are responsible for, or at least are accompaniments of, the disruptive effects of urea on the components of the tissue cells to which presumably it owes its toxicity.

\section{REFERENCES}

1. Grollman, A. Acute Renal Failure. Springfield, Ill., Chas. C Thomas, 1954, p. 63.

2. Grollman, A., Turner, L. B., and McLean, J. A. Intermittent peritoneal lavage in nephrectomized dogs and its application to the human being. A.M.A. Arch. intern. Med. 1951, 87, 379.

3. Van Slyke, D. D., and Cullen, G. E. A permanent preparation of urease, and its use in the determination of urea. J. biol. Chem. 1914, 19, 211.

4. Laramore, D. C., and Grollman, A. Water and electrolyte content of tissues in normal and hypertensive rats. Amer. J. Physiol. 1950, 161, 278.

5. Grollman, A. The vapour pressures of aqueous solutions with special reference to the problem of the state of water in biological fluids. J. gen. Physiol. $1931,14,661$.

6. Ralls, J. O., and Crohn, E. B. Urea is not equally distributed between the water of the blood cells and that of the plasma. J. biol. Chem. 1943, 151, 529.

7. Grollman, A. Water and electrolyte content of the tissues of the adrenalectomized and adrenalectomized-nephrectomized dog. Amer. J. Physiol. 1954, 179, 36.

8. Burk, N. F., and Greenberg, D. M. The physical chemistry of the proteins in non-aqueous and mixed solvents. I. The state of aggregation of certain proteins in urea-water solutions. J. biol. Chem. 1930, 87, 197.

9. Huggins, C., Tapley, D. F., and Jensen, E. V. Sulphydryl-disulphide relationships in the induction of gels in proteins by urea. Nature (Lond.) 1951, $167,592$.

10. Mathieson, A. R., and Porter, M. R. The effect of urea on the streaming birefringence and viscosity of sodium deoxyribonucleate. J. chem. Soc. 1958, 1298.

11. Ruffo, A., Santamaria, R., and Mattace-Raso, F. The denaturation of serum proteins by urea. Boll. Soc. ital. Biol. sper. 1955, 31, 1381.

12. Schiano, S., and D'Onofrio, F. Experimental uremia. Residual and urea nitrogen. Sperimentale 1957, 107, 435.

13. Hamburger, J. Electrolyte disturbances in acute uremia. Clin. Chem. 1957, 3, 332. 